\title{
The Correlation between Figural and Conceptual Properties of Angle and Cube in Pre-Service Teachers Geometric Reasoning ${ }^{2}$
}

\begin{abstract}
Summary: Drawing upon Fischbein's theory of figural concepts, the starting point of the paper is the use and value of the history of geometry in mathematics education - first point that we make historical reference are theorems of Eudemus of Rhodes and Thales of Miletus and the second one is elaboration of these theorems in work of Serbian mathematicians Mihailo Petrović Alas. Fischbein's theory is mainly based on a hypothesis that geometry deals with mental entities, the so-called geometric figures, which simultaneously possess conceptual and figural properties. Fischbein called the geometric figures figural concepts because of their nature. We have analyzed the internal tensions of the concepts of angle and cube, which may appear in figural concepts because of their double nature, developmental aspects and didactical implications. The goal of the research was to examine the preservice primary school teachers' geometric reasoning regarding the correlation between figural (pictoral) and conceptual properties of geometric objects (angle and cube) in order to obtain a framework for creating didactic situations that reduce the gap between figure and concept. The results of this study show that the figural (pictoral) structure of an angle (and cube) dominates in the geometric reasoning of the pre-service primary school teachers over its formal conceptual constraints. There were some differences in situations when an image is helpful in solving tasks involving the concepts of the net of the cube and the cube itself.
\end{abstract}

Keywords: history of geometry, figural concept, geometric definition, instruction, geometric reasoning.

\footnotetext{
1 olivera.djokic@uf.bg.ac.rs

2 The paper is a part of the project entitled “The Concepts and Strategies for the Quality Assurance in Initial Education" No. 179020, and carried out by the Teacher Education Faculty of the University of Belgrade, Republic of Serbia.

Copyright $\odot 2020$ by the authors, licensee Teacher Education Faculty University of Belgrade, SERBIA.

This is an open access article distributed under the terms of the Creative Commons Attribution License (CC BY 4.0) (https://creativecommons.org/licenses/by/4.0/), which permits unrestricted use, distribution, and reproduction in any medium, provided the original paper is accurately cited.
} 


\section{Introduction}

Drawing upon the theoretical framework of development of students' geometric thinking (Dreyfus, 2014; Đokić \& Zeljić, 2017), students' geometric reasoning (Đokić \& Zeljić, 2017) and Fischbein's theory of figural concepts (Fischbein, 1993), the authors of the paper explore the use and value of the history of geometry in mathematics education (Dejić, 2001; 2013; 2020; Đokić, 2017; Đokić et al., 2019; Gulikers \& Blom, 2001) as the starting point in their research. The main hypothesis of Fischbein's theory (1993) is that geometry deals with mental entities, the so-called geometric figures that simultaneously possess conceptual properties (such as ideality, abstractness, generality) and figural properties (such as shape, position, magnitude). Fischbein called the geometric figures figural concepts because of their nature. We shall analyze the internal tensions according to Fischbein (1993) which may appear in figural concepts because of their double nature, developmental aspects and didactical implications. In our paper we started the research idea (Đokić et al., 2019), and now we shall further develop it. The theoretical framework that we used as our starting point comes from the history of mathematics for constructing mathematical knowledge in the spirit of the research conducted by Furinghetti (2019). From the history of mathematics we used as a starting point the theorems of Eudemus of Rhodes and Thales of Miletus, and after that the elaboration of these theorems by Mihailo Petrović Alas, a famous Serbian mathematician (in Dejić, 2020: 98).

\section{Theoretical background}

The relationship between a definition and an image is viewed differently in empirical sciences and mathematics (Fischbein, 1993). In empirical sciences, definition is ultimately determined by the properties of its objects, whereas in mathematics definition, created directly or by deduction, is the property of the corresponding objects. Therefore, the interpretation of the figural components of geometric figures should entirely be subjected to formal constraints. This idea is not always clearly understood and students often tend to overlook it. The difficulty with manipulating figural objects lies in a tendency to disregard the definition due to figural constraints which are the main obstacle to students' geometric reasoning.

There are theories of geometric figure analysis, such as Duval (1998), which show that, in many cases, the visual management and analysis of the geometric figure has specific and autonomous features originating from the Gestalt lows (Đokić, 2017; Gal \& Linchevski, 2010; Lemonidis, 1997). The Gestalt school claimed that the perception of form is considered as a unitary global structure. The organization of shapes and objects was extracted from the visual scene into groups to form the object (Gal \& Linchevski, 2010). According to Gal and Linchevski, this theory provides a possible analysis to overcome difficulties in geometry which might occur during a perceptual organization of geometrical configuration. Duval (1998) asserts that a configurative process is independent of the logical process involved. Thus, visualization is crucial in the configurative process.

Logic and image are two objects of different nature from psychological and epistemological points of view. From the epistemological point of view, we are dealing with logical and factual propositions (of a figure). In the process of drawing an image (figure), figural elements become a part of logical conclusions. From the psychological point of view, we are dealing with a concept image (of a geometric figure). Psychological processes occur internally at the level of an individual. Tall and Vinner (in Bingolbali \& Monaghan, 2008: 20) describe the concept image as a total cognitive structure associated with a concept in an individual's mind. It includes mental pictures, associated properties and processes, as well as words and symbols.

Vinner and Hershkowitz (in Dreyfus, 2014: 50) were the first researchers who pointed out that students' geometric reasoning is not based on definitions, but on prototypical examples. Prototypical ex- 
amples are typical examples or representations of a concept (Guo \& Pang, 2011; Lemonidis, 1997; Tsamir et al., 2015). According to Herschkowitz (in Lemonidis, 1997: 2089), the prototypical examples were usually the subset of examples with the 'longest' list of attributes, all the critical attributes of the concept, and those specific (noncritical) attributes that had strong visual characteristics. A prototypical example of the altitude of a triangle is the one that lies inside the triangle and it is perpendicular to a horizontally drawn base of the triangle parallel to the lower edge of the school board on which the triangle is drawn. This is based on the experience of students who have seen many examples of triangles where the altitude belongs to the inner area and it is positioned vertically, whereas there are only a few examples where it is positioned differently. Vinner and Hershkowitz go as far as to claim that students tend to treat as exceptions some examples where such properties (attributes) of geometric objects are not present, even if they know the (general) definition of the altitude of a triangle. The didactical situations that we are dealing with in the paper arise when pre-service primary school teachers should base their reasoning on the definition of a given concept (they are aware of the definition and they can explain it), but they base it on something else instead. Vinner, Hershkowitz and Tall (in Dreyfus, 2014: 51) proposed the term concept image for that 'something else.' They describe 'something else' as the set of all pictures that have ever been associated with the concept in the student's mind, and then they concretize 'something else' in geometry as the total cognitive structure that is associated with the concept, which includes all the mental pictures and associated properties and processes. It is built up over the years through experiences of all kinds, changing as the individual meets new stimuli and matures. Dreyfus (2014) observes that this structure may not be generally coherent and can partly deviate from the formal definition of the concept. Therefore, Vinner, Hershkowitz and Tall hold that in mathematics education the cognitive processes by which concepts are conceived must be distinguished from the mathemat- ical concepts as formally defined. Edwards and Ward (2004) claim that when the concept definition conflicts with the concept image, the concept image wins.

Edwards and Ward (2008) wrote about definition activities and pedagogical objectives that could: a) promote a deeper conceptual understanding of the mathematics involved, b) promote understanding of the nature or the characteristics of mathematical definitions, and/or c) promote understanding of the role of definitions in mathematics. Vinner (2018) concludes that students' awareness of mathematical definitions (even the informal ones), not only of concept images, plays a crucial role. This author also claims that mathematical definitions are likely to inhibit spontaneous reactions caused by concept images and concludes that here we are dealing with the process from intuition to inhibition (Viner, 2018). Fischbein (in Kidron, 2011: 1265) recommends that a situation should be created in which a conflict appears between the intuitive reaction to a given situation, and the cognition reached through a logical analysis. For the situations occurring in his research on a horizontal asymptote, Kidron proposes the (re)construction of the knowledge of the definition of the horizontal asymptote as a limit.

Fischbein (1993) offers an example of how to help students to cope with this type of conflict situation. Students may not be able to draw correctly the altitude of the triangle ABC from vertex B (Figure 1), and they will draw BD instead, despite the fact that they know the definition of the altitude of the triangle.

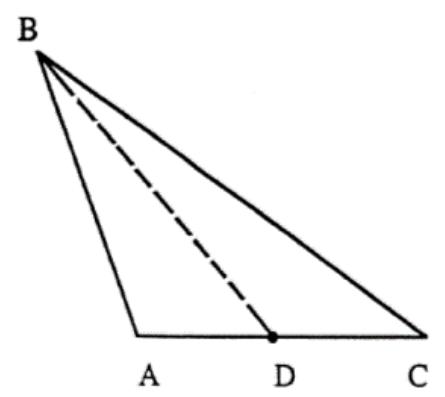

Figure 1. The problem with drawing a triangle altitude according to Fischbein (1993: 154). 
The students should know the definition and solve the task by following it, and not according to what they think they see in the image. Many similar examples should be systematically used in the classroom so that the domination of the definition over the image in the interpretation of figural concepts becomes absolutely clear to all students.

Fischbein provides another example. In this task, students have to compare the set of points in the segments $\mathrm{AB}$ and $\mathrm{CD}$ and to resolve the conflict between two claims: that $\mathrm{CD}$ has more points than $A B$ and the claim that two sets of points $A B$ and $C D$ are mutually equivalent (Figure 2).

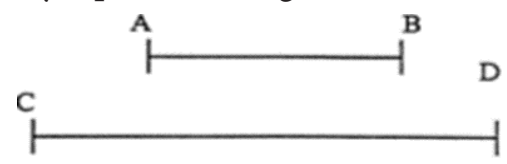

Figure 2. Comparing the sets of points according to Fischbein (1993: 155).

The integration of conceptual and figural properties, with the predominance of conceptual constraints over the figural ones, according to Fischbein, is not a natural process. Fischbein (1993: 154-156) claims that "the processes of building figural concepts in the students' minds should not be considered a spontaneous effect of usual geometry courses". This process requires teachers' continual, systematic, and committed involvement. Conflict situations should serve to teach students how to follow carefully the requirements set in definitions, which sometimes can run contrary to what the images seem to represent (or impose).

We determined two points that correlate with two historical references related to this paper and represent the contribution of the paper to mathematics education from the perspective of the history of mathematics.

The first point of historical reference - the theorems of Eudemus of Rhodes and Thales of Miletus. We found these theorems in Fischbein's work. Fischbein (1993) asks a question whether a circle is only an image (i.e., spatial representation). Accord- ing to Fischbein, its existence and properties are imposed by an abstract, formal definition. For this reason, he proposes that the circle should be treated as a figural concept. Let us determine the correspondence of the points of the circle and then define it metrically or algebraically. All the points of the circle are equidistant (radius $\mathrm{r}$ ) from the point $\mathrm{O}$ (the center of the circle) and all the points equidistant from $\mathrm{O}$ are situated on the circle (see Figure 3). Algebraically, this is expressed by the following formula: $(x-a)^{2}+(y-b)^{2}=r^{2}$.

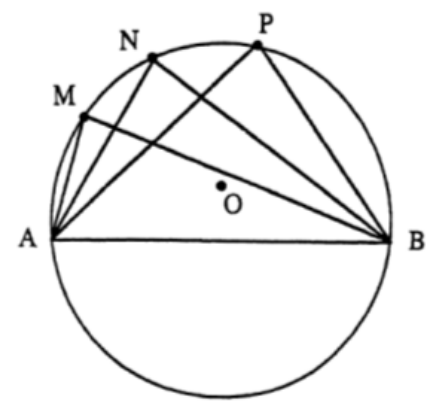

Figure 3. Comparing the angles directly and figurally according to Fischbein (1993: 157).

Let us select two points, A and B, on the circle, and draw several angles over the segment $A B$, with vertices $M, N$, and $P$ (forming triangles $A M B$, $\mathrm{ANB}$, and $\mathrm{APB})$. It is difficult to compare the triangles directly and figurally (by relying on the image). The angles seem to be different for some people or to be equal for some other. It depends on how they see these angles. If one compares the angles with the wrong view of the length of their sides then they could look uneven. However, there is a theorem stating that in a circle, two peripheral angles with the same interception are congruent (Eudemus of Rhodes, 370 BCE - 300 BCE, philosopher, considered the first historian of science, believes that the theorem was put forward by Thales of Miletus, $624 \mathrm{BC}-$ 546 BC). Therefore, the three angles with the vertices $\mathrm{M}, \mathrm{N}$, and $\mathrm{P}$ are also equal. We are dealing here with figural concepts where all parts of the image (angles, sides, points, the circle, the arc) are simultaneously images and concepts (images are controlled 
by their definitions). However, it is obvious that in the process of reasoning the image cannot provide an answer to the posed question. The equality of the angles is determined by the theorem. Therefore, we can conclude that the image can lead to incorrect reasoning (drawing conclusions). All the vertices of the angles whose sides pass through the same points of the circle and have the same magnitude as the angle whose vertex lies on the circle are placed on the same circle. Fischbein believes that confronting figural impressions with formal constraints improves conceptual control and stimulates the merging of figural and conceptual constraints.

The second point of historical reference has been made with regard to the work of Mihailo Petrović Alas. We will show the relationship between the notes of Mihailo Petrović Alas and the direction of Fischbein's view on geometric figures. Mihailo Petrović Alas, a well-known Serbian mathematician (1868-1943) (Andrić, 2018; Dejić, 2001; 2013; 2020; Lawrence, 2014), explored this problem area at the end of the 19th and the beginning of the 20th century. He proposed several situations that teachers should use when helping students to develop geometric reasoning when drawing geometric figures.

Dejić $(2001 ; 2020)$ observes that Petrović used several examples to demonstrate how a small, and seemingly irrelevant mistake, that is often impossible to spot while drawing, leads to entirely incorrect geometrical conclusions, despite the fact that the given image is interpreted most correctly and accurately. Dejić (2001) offers an interpretation of the history instruction of Petrović (see Figure 4). Let us assume that AFB is an angle. Then we draw perpendiculars from the points $A$ and $B$, located on the sides of this angle. Point $C$ is their intersection. Then we draw a circle through the points A, B, and C. The points $\mathrm{D}$ and $\mathrm{E}$ are the intersections of the circle with the sides of the angle AFB.

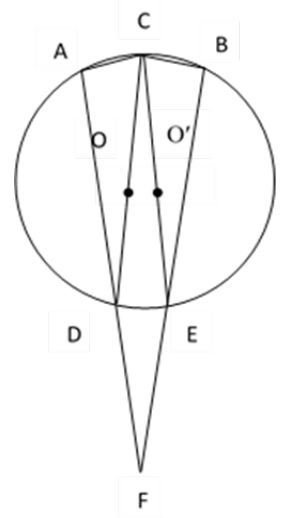

Figure 4. An incorrectly drawn image according to Mihailo Petrović Alas (in Dejić, 2001: 618).

As the angle DAC is a right angle, the segment $\mathrm{DC}$ is one diameter of the circle, and $\mathrm{O}$ is the center of the circle. Because $\mathrm{EBC}$ is a right angle, $\mathrm{EC}$ is one diameter of the circle, and O' of the diameter is also the midpoint of the same circle. The conclusions drawn from the image are apparently correct. It turns out that this circle has several centers. Then where was the mistake made? If we had drawn the image correctly, we would have noticed that the circle must pass through the point $\mathrm{F}$, and not through the points $\mathrm{D}$ and $\mathrm{E}$ on the sides of the angle. In that case, the points $\mathrm{D}$ and $\mathrm{E}$ coincide with the point $\mathrm{F}$, both parameters coincide with the diameter $\mathrm{CF}$, and both centers fall into one point, in the real center of the circle. Dejić (2001) interprets Petrovićs conclusions in the following manner: 1 . by applying the right reasoning, the incorrect result was obtained from the incorrectly drawn image and 2 . to avoid serious mistakes, drawing should be as precise as possible. The precise drawing enables us to see the details that we otherwise wouldn't pay attention to, such as the intersection of straight lines or arcs in the same point. Mihailo Petrović Alas points out the correct construction of the geometric shape because a wrong construction leads to incorrect geometric conclusions.

Through Fischbein's theory of concept image, we discuss the dual dimension of geometrical fig- 
ure as a geometric shape and as geometric properties. The above notes of Mihailo Petrović Alas also refer to this dual hypostasis of the geometrical figure because he indicates that if through the geometrical construction the image becomes wrong then and the other part of the geometrical concepts will be wrong.

According to Fischbein (1993), students have to learn to mentally manipulate geometric objects and, at the same time, apply operations with figures, logical correlations and operations. These mental activities involve the completion of the following tasks: 1. drawing an image by unfolding a geometrical object and obtaining a folding (observed in reality or mentally represented), 2. identifying a geometrical object that can be created by imagining a twodimensional image, and 3. asking students which sides or faces of a geometric object will join when the three-dimensional object is reconstructed. It is relatively easy to determine that Figure 5 represents the net of a cube. It is more difficult to see (imagine) that the marked sides (faces 4 and 5 marked by arrows in Figure 5) also meet in the folded cube.

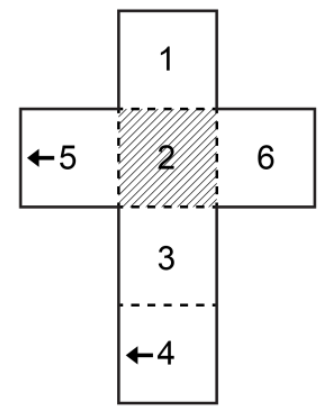

Figure 5. A possible shape of the net of a cube according to Fischbein (1993: 158).

Identifying the net of a cube in Figure 6 would be even a more complex task. Similarly, it is not easy to realize that the marked sides (faces 1 and 6 marked by arrows in Figure 5) match in the reconstructed cube.

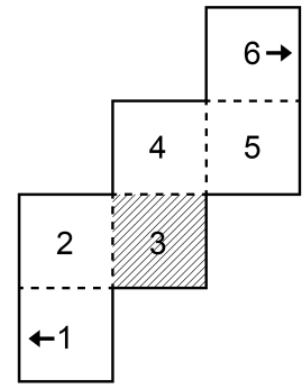

Figure 6. Another possible shape of the net of a cube according to Fischbein (1993: 159).

Fischbein further elaborates on the contribution of figural manipulations and logical operations. Images and concepts are generally considered to be separate categories of mental activities. When different types of mental transformations of threedimensional objects are explored (such as rotation or folding and unfolding of figures), we realize that students deal with these operations as if they were of purely pictorial nature. But this is not true and it cannot be true because we are dealing with the faces of the cube (the examples provided above) with the sides of equal length, all the faces are squares, there are right angles, etc. This is all tacit knowledge which is implied in performing mental operations. Without such tacit conceptual control, the entire operation would be meaningless. Figural manipulation and mental logical operations contribute to the understanding of the concept and represent an opportunity for training the capacity of handling figural concepts in geometrical reasoning. The aim of such training would be the improvement of the following capacities: a constructive cooperation of figural and conceptual aspects of the activities for problem solving; coordination among as many figural-conceptual items as possible; organizing mental processes by using meaningful sub-units to reduce memory overload and anticipation; and, anticipating and connecting all the changes on the road to the final solution. Images and concepts interact in a cognitive activity (of children or adults) by cooperating in some situations or confronting one another 
in some other situations. However, the development of figural concepts is not a natural process. One of the main reasons why the topics related to geometry are so difficult in the school curricula is that figural concepts do not develop naturally, according to their ideal forms. For this reason, the formation of different types of didactical situations requiring a strict cooperation between an image and a definition and reduce the gap between them.

\section{Methodology}

The goal of our research was to examine the correlation between figural (pictorial) and conceptual properties of geometric objects. The research objectives were formulated as follows:

1. To investigate whether the figural (pictorial) structure of an angle (and cube) dominates in the geometric reasoning of the pre-service primary school teachers over their formal conceptual constraints;

2. To investigate in which situations an image can help the pre-service primary school teachers' reasoning when there is a domination of one of the two above-mentioned aspects over the other - figural (pictorial) structure and the corresponding formal constraints of the concept (angle and cube).

The general research hypothesis is that an image plays an important role in the pre-service primary school teachers' reasoning, i.e., that students tend to overlook the formal constraints of the concept (angle and cube) in the tested situations.

The research sample consisted of 64 fourthyear students of the Teacher Education Faculty in Belgrade, Serbia (pre-service teachers). These students constituted a non-random convenience sample.

Research method. A descriptive method and testing as a technique were used in the research. The obtained data were analyzed quantitatively and qualitatively. The software program SPSS (Version 22) was used for the quantitative data processing. The data were analyzed by using the non-parametric tests, the Wilcoxon signed-rank test, the Chi-square test of independence, Phi correlation coefficient, and the Chi-square test of homogeneity (Franke at al., 2012). Whenever the requirement for the Chisquare test was not met, the Fisher's Exact Test was used instead.

The research procedure. The tasks involving the relationship between the figural (pictorial) and conceptual aspects of geometric objects were a part of the test that the fourth-year students (pre-service teachers) have to complete as their pre-exam requirement for the subject Didactic of Mathematics II. After the time set for doing the test was over, the tests were collected and the students were given another test with two tasks repeated, both dealing with the net of a cube, but now there was an additional instruction: they had to sketch and mark how the cube would look like if the net of a cube were folded. The tasks are described and presented in the section of the paper dealing with the research results.

\section{Results and discussion}

The first research objective. We investigated the relationship between the figural (pictorial) and conceptual aspects of an angle in the pre-service primary school teachers, and whether an image affects the students' reasoning. The students were given a task (Figure 7) to write a definition of an angle, then to determine which points belong to the angle in the image in two examples, where one example is a prototypical presentation of an angle and the other one is not (Al-Murani at al., 2019; Guo \& Pang, 2011). As in Fischbein and Nachlieli (1998), the task questions were simple and focused on the concept of an angle, given that too complex instructions can obstruct the analysis. 
1. a) Define an angle.

b) Write which points in the image belong to $\angle \mathrm{A}$.

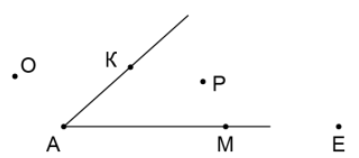

c) Write which points in the image belong to $\angle \mathrm{A}$.

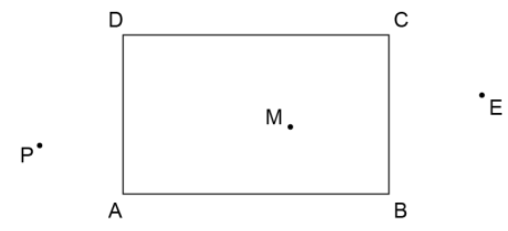

Figure 7. The task dealing with the concept of an angle.

As far as the definitions of an angle are concerned, we accepted as correct the definitions with some minor imprecisions, given that the precision of mathematical language was not tested in the research. The achievement of the students in this task is shown in Table 1. The students were most successful in defining an angle, while they were less successful in identifying which points belong to the prototypical image of an angle. The lowest achievement was observed in the task of identifying which points belonged to an angle of one vertex of a polygon (rectangle).
Table 1. Achievement at the task involving the concept of an angle.

\begin{tabular}{lcc}
\hline & $\begin{array}{c}\text { correct } \\
\mathrm{f}(\%)\end{array}$ & $\begin{array}{c}\text { incorrect } \\
\mathrm{f}(\%)\end{array}$ \\
\hline $\begin{array}{l}\text { Definition of an angle } \\
\text { The points appertaining to an } \\
\text { angle }\end{array}$ & $36(56.3 \%)$ & $28(43.7 \%)$ \\
$\begin{array}{l}\text { The points appertaining to an } \\
\text { angle of a polygon (rectangle) }\end{array}$ & $10(15.6 \%)$ & $54(84.4 \%)$ \\
\hline \multicolumn{1}{c}{$\mathrm{N}=64$} & & $42(65.6 \%)$ \\
\hline
\end{tabular}

We also wanted to find out whether there was any correlation between the students' level of achievement on the task involving a definition of an angle and their achievement on the task dealing with the prototypical image of an angle. As the Chi-square test of independence rejected the null hypothesis, we can conclude that there is a correla- 
tion between the two variables $\left(\chi^{2}(1,64)=8.905\right.$, $\mathrm{p}<0.05$, phi $=0.373)$. According to Cohen's criteria (Cohen, 1988), the level of correlation between the two variables is considered medium to strong. Crosstabulation provides an important insight into the nature of this relationship (Table 2).

Table 2. Crosstabulation of achievement on the tasks testing the definition

of an angle and the point appertaining to an angle.

\begin{tabular}{|c|c|c|c|c|c|}
\hline & & & \multicolumn{2}{|c|}{ Point appertaining to an angle } & \multirow[t]{2}{*}{ Total } \\
\hline \multirow{7}{*}{ 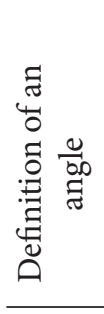 } & & & incorrect & correct & \\
\hline & \multirow[t]{3}{*}{ incorrect } & $\mathrm{f}$ & 24 & 4 & 28 \\
\hline & & $\%$ definition of an angle & $85.7 \%$ & $14.3 \%$ & $100.0 \%$ \\
\hline & & $\%$ point appertaining to an angle & $57.1 \%$ & $18.2 \%$ & $43.8 \%$ \\
\hline & \multirow[t]{3}{*}{ correct } & $\mathrm{f}$ & 18 & 18 & 36 \\
\hline & & $\%$ definition of an angle & $50.0 \%$ & $50.0 \%$ & $100.0 \%$ \\
\hline & & $\%$ point appertaining to an angle & $42.9 \%$ & $81.8 \%$ & $56.3 \%$ \\
\hline \multirow{3}{*}{\multicolumn{2}{|c|}{ Total }} & $\mathrm{f}$ & 42 & 22 & 64 \\
\hline & & $\%$ definition of an angle & $65.6 \%$ & $34.4 \%$ & $100.0 \%$ \\
\hline & & $\%$ point appertaining to an angle & $100.0 \%$ & $100.0 \%$ & $100.0 \%$ \\
\hline
\end{tabular}

Out of 36 students who defined an angle correctly, one half identified the points appertaining to an angle correctly. On the other hand, 24 students, out of 28 who defined an angle incorrectly, did not identify the points appertaining to an angle correctly. Therefore, the more successful the students are at defining an angle, the greater the chance that they will do the task successfully by using an image. However, we consider it important to note that a half of the students who defined an angle correctly failed to identify all the points appertaining to the angle presented in the image, which indicates that there is an internal conflict in students between an image and the concept of an angle. The previous research (Clements \& Battista, 1992, in Sinclair, \& Bruce, 2015: 323; Hershkowitz, 1987) showed that learners, pre-service primary school teachers and in-service teachers struggle with matching prototypical images with definitions. According to Vinner (in Tsamir et al., 2015: 498), as concept images are not always aligned with formal conceptual definitions, this discrepancy can create a conflict, i.e., a learner who knows a formal definition invariably relies on a concept image in completing a task, not on his/her knowledge of the definition.

The mistakes that the students had made in solving the tasks using an image, particularly the points appertaining to an angle that the students failed to identify, were also analyzed. In the first task, example b) (see Figure 7), as many as 35 students most often did not mark the vertex A, while 18 students overlooked the point E placed in the extension of the side of the angle, and 13 students overlooked the point $\mathrm{P}$ situated inside the angle. Three students respectively overlooked the points $\mathrm{K}$ and $\mathrm{M}$ situated on the sides of the angle. One respondent failed to determine any of the points. We do not have an explanation for why they missed to mark the point A, maybe they thought that it goes without saying, as Duval (1998) mentions in a configu- 
rative process. Therefore, it is interesting to explore this question in the future research. The next most common point they did not mark is point $\mathrm{E}$, which was expected, considering the restraints of the image of an angle.

We also wanted to investigate whether an image impacts the pre-service primary school teachers' reasoning, i.e., how students understand the concept of an angle in geometric figure. Their achievement in identifying the points appertaining to an angle in a prototypical image was compared with the same instruction in the image of an angle at the vertex $\mathrm{A}$ of a rectangle $\mathrm{ABCD}$. We concluded that the students were statistically more successful at identifying the points appertaining to an isolated angle than at identifying the points appertaining to an angle in geometric figure (Fisher's Exact Test, $\mathrm{p}=0.002$ ). This result indicates that an image has a considerable impact on students' successful identification of the points appertaining to an angle, which is further indicative of the fact that pre-service primary school teachers do not have a thorough conceptual understanding of the concept of an angle. Drawing upon the theory of visual perception, Gal and Linchevski (2010) explain that prototype images are perceived and analyzed by means of sensory stimulus. In our case, identifying the position and the elements of an angle is an automatic process. However, if a geometric object is rotated differently, or presented under specific conditions, its analysis requires an attention and conscious control. In order to determine successfully which points appertain to an angle, in both examples, the students first automatically recognize the angle (bottom-up processing), and then, by relying consciously on the acquired knowledge, they determine which points appertain to the given angles (top-down processing), which is even more complicated in the case of an angle in a polygon (rectangle).

In the same task, example c) (see Figure 7), 38 students overlooked the point $\mathrm{E}$ situated inside the angle, close to the vertex $\mathrm{B}$ of the rectan- gle $\mathrm{ABCD}$, but outside the rectangle, while only five students overlooked the point $\mathrm{M}$ situated both inside the angle and the rectangle. It seems that the sides of the rectangle somehow limited the angle in the respondents' perception. In this example as well, the vertex was the point frequently overlooked by the students, as many as 35 times, and this point is also the vertex of the rectangle $\mathrm{ABCD}$. The point $\mathrm{C}$, which is also the vertex of the rectangle, was overlooked by 32 students. The point $\mathrm{D}$ was overlooked by 13 students and 12 students overlooked the point B. Both points are the vertices of the rectangle and are situated on the sides. Four students did not identify anything, while five students identified only the point $M$. We were surprised to find out how many pre-service primary school teachers overlooked the point A, i.e., the vertices in the images of an angle. Despite the fact that they determined the common starting point of the two semi-straight lines in the definition of an angle, as many as 25 students did not identify the point A in the prototypical image, and 28 students failed to identify it in the image of an angle in a rectangle.

Based on these results, we concluded that conceptual and figural (pictorial) aspects were not harmonized (Fischbein, 1993; Fischbein \& Nachlieli, 1998), but also that an image played an important role in the pre-service primary school teachers' reasoning.

The aim of the second task was to investigate the role of the figural (pictorial) aspect in students' reasoning and to get an insight into their knowledge of the formal aspects of the concepts related to the concept of an angle. The task involved analyzing the correlations between a straight line and a segment, two semi-straight lines, as well as between two segments, by asking the students to mark the common point of two geometric objects (Figure 8). 
2. In the images below, mark the common points of:

a) The segment $\mathrm{AB}$ and the straight line $a$

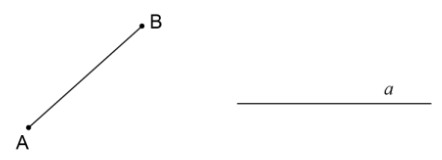

b) the semi-straight line $\mathrm{O} a$ and the semi-straight line $\mathrm{Ap}$

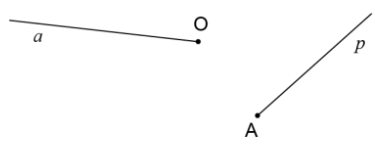

c) the straight line $a$ and the segment $\mathrm{AB}$

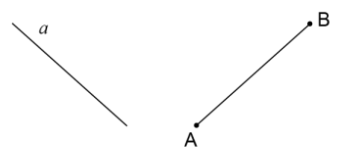

d) the segment $\mathrm{AB}$ and the segment $\mathrm{SM}$

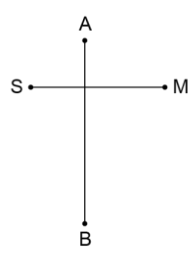

Figure 8. The task involving the concepts of a segment, a straight line, and a semi-straight line.

The achievement on this task was high (Table 3). More than three-fourths of the students did all the examples correctly.

\section{Table 3. Achievement on the task involving the} concepts of a segment, a straight line, and a semistraight line.

\begin{tabular}{lcc}
\hline & $\begin{array}{c}\text { correct } \\
\mathrm{f}(\%)\end{array}$ & $\begin{array}{c}\text { incorrect } \\
\mathrm{f}(\%)\end{array}$ \\
\hline Segment and straight line & $56(87.5 \%)$ & $8(12.5 \%)$ \\
Two semi-straight lines & $50(78.1 \%)$ & $14(21.9 \%)$ \\
Straight line and segment & $51(79.7 \%)$ & $13(20.3 \%)$ \\
Two segments & $59(92.2 \%)$ & $5(7.8 \%)$ \\
\hline $\mathrm{N}=64$ & & \\
\hline
\end{tabular}

Students demonstrated that they understand that the drawn segments of the straight line and the semi-straight line do not represent their endings. Given that the semi-straight lines are the elements of an angle, we tried to crosstabulate the data pertaining to the results on this task with the results on the angle-related task. Our specific point of interest was the high success rate presented in Figure 8, example a) where students were extending the straight line $a$ to mark the point of intersection with the segment $\mathrm{AB}$, while, on the other hand, most of them did not write that the point $\mathrm{E}$, located on the extension of the semi-straight line, belongs to the angle presented in the image (Figure 7, example b). Though there 
is a correlation between these geometric objects, the students' answers show the opposite (Table 4).

The Phi correlation coefficient did not show any significant correlation among the students' responses ( $p h i=0.168, p>0.05)$. Nearly one-third of the tested students, 19 in total, did not notice that the point $\mathrm{E}$, placed on the extension of the side, appertains to the given angle, and out of these 19 students, as many as 15 were able to solve the task in which the point of intersection with the drawn segment is created by extending the straight line. Based on this result, it can be concluded once again that an image plays an important role in students' reasoning because they disregard the conceptual knowledge of the straight line and the semi-straight line as (un) limited lines when observing the figure of an angle.

The second research objective. We investigated in what situations the figural (pictorial) aspect of a concept can improve the pre-service primary school teachers' geometric reasoning. The students had to solve two tasks related to folding of a net of a cube. The purpose of the repeated test and the additional instruction to draw a folded cube was to deter- mine whether in that case the students' achievement would be better. In the course of the test procedure, we were faced with a problem of a reduced sample because some students had not drawn an image at the repeated test. The students who had drawn an image at the first test were also left out from the analysis. Out of 64 students who did the test, 34 fulfilled the requirement for the first task, and 28 students for the second task.

The first task related to the concepts of a cube and the net of a cube contained three instructions (Figure 9, the idea is from the task in Shimizu et al., 2012: 93). Each correct answer to the instruction was allotted one point. In the first instruction, the students were asked to write down which side will overlap the side $\mathrm{AB}$ in the process of folding the net of the cube. In the other two instructions, the students were asked to write down which sides start at the vertices $C$ and $K$.

The achievement on this task is presented in Table 5. Nearly one-third of the students provided answers to all three instructions in the task 3 , as well as in the repeated task.

Table 4. The achievement correlation related to the appertaining of the point $E$ to an angle and segment and straight line.

\begin{tabular}{|c|c|c|c|c|c|}
\hline & & & \multicolumn{2}{|c|}{ Point $\mathrm{E}$ appertaining to an angle } & \multirow[t]{2}{*}{ Total } \\
\hline \multirow{7}{*}{ 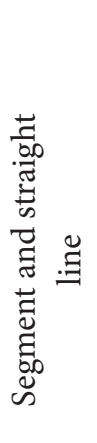 } & & & incorrect & correct & \\
\hline & incorrect & $\mathrm{f}$ & 4 & 4 & 8 \\
\hline & & $\%$ segment and straight line & $50.0 \%$ & $50.0 \%$ & $100.0 \%$ \\
\hline & & $\%$ point $\mathrm{E}$ appertaining to an angle & $21.1 \%$ & $8.9 \%$ & $12.5 \%$ \\
\hline & correct & $\mathrm{f}$ & 15 & 41 & 56 \\
\hline & & $\%$ segment and straight line & $26.8 \%$ & $73.2 \%$ & $100.0 \%$ \\
\hline & & $\%$ point $\mathrm{E}$ appertaining to an angle & $78.9 \%$ & $91.1 \%$ & $87.5 \%$ \\
\hline & Total & $\mathrm{f}$ & 19 & 45 & 64 \\
\hline & & $\%$ segment and straight line & $29.7 \%$ & $70.3 \%$ & $100.0 \%$ \\
\hline & & $\%$ point $\mathrm{E}$ appertaining to an angle & $100.0 \%$ & $100.0 \%$ & $100.0 \%$ \\
\hline
\end{tabular}


3. Below is a net of a cube. If you built the net to form the cube:

a) Which side would join side $A B$ ?

b) Write all of the sides that would join in vertex $\mathrm{C}$

c) Write all of the sides that would join in vertex $\mathrm{K}$

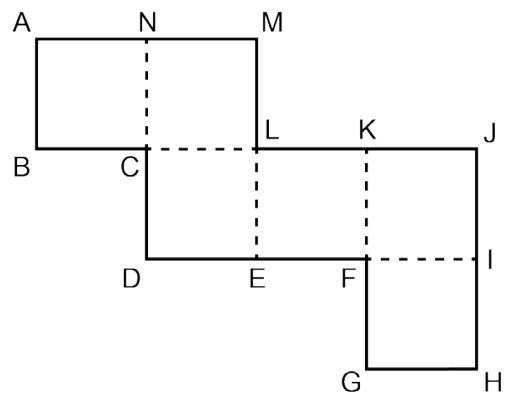

Figure 9. The first task related to the concepts of a cube and the net of a cube.

4. Imagine that you build the net of the cube below.

a) Which face is parallel to face $d$ ?

b) Write all of the faces that are perpendicular to the face a.

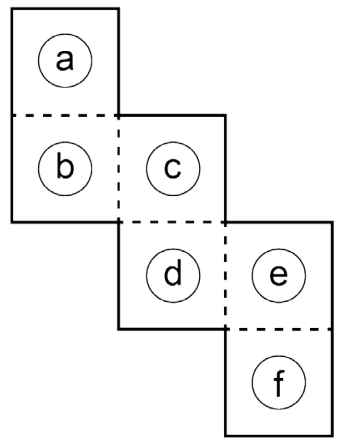

Figure 10. The second task related to the concepts of a cube and the net of a cube (Shimizu et al., 2012: 93).

The second task related to the concepts of a cube and the net of a cube contained two instructions. Each correct answer to the instruction was allotted one point. In the first instruction students had to answer which face of the cube is parallel to the face $d$, and in the second one they were asked to write down all the faces perpendicular to the face $a$ (Figure 10).

The achievement on this task is presented in Table 6. One half of the students provided correct answers to both instructions, while the success rate was higher at the repeated test. 
We tried to determine if there were any significant differences in terms of students' achievement on the test with tasks involving the folding of a net of a cube without using an image and on the test with tasks where they were instructed to use an image. The results obtained on the first task related to the concepts of a cube and the net of a cube and the results on the repeated task indicate no significant changes in the students' achievement (Wilcoxon signed-rank test, $\mathrm{z}=-1.051, \mathrm{p}>0.05, \mathrm{r}=0.13$, $\mathrm{Md}=2$, Mdrepeated =2). However, the results obtained on the second task, show a significant change in the students' achievement related to the concepts of a cube and the net of a cube and on the repeated task, indicating a medium to large difference between the two results $(r=0.40)$ (Cohen, 1988) (Wilcoxon signed-hrank test, $\mathrm{z}=-2.975, \mathrm{p}<0.05, \mathrm{Md}=$ 1.5 , Mdrepeated $=2$ ). These results may provide an answer to the question of when an image can help students to solve the tasks involving the folding of the net of a cube. Namely, if we look at the nature of the tasks, it becomes obvious that the first task related to the concepts of a cube and the net of a cube is much more difficult than the second task related to the concepts of a cube and the net of a cube, given that the instruction refers to the overlapping sides and vertices, while the instructions in the second task refer to the positions of the faces of the cube. The results on these two tasks support this observation. Therefore, it can be concluded that an image used in the folding of a net of a cube can help students when the visualization is made easier, where- as in the contrary case, students cannot draw the figure successfully and will not be able to solve the more complex tasks involving the folding of a net of a cube. Nonetheless, as the research sample was small, this issue should be further explored by using a measurement instrument that meets all metric properties of the knowledge test and on a sample of normal distribution.

We were interested in the errors students made, and here we analyse these tasks considering our first research objective. The error analysis showed that there is a tension between the definitions and figural representations. In the first task (see Figure 9), the instruction was to write down the sides of the cube starting at the vertices $C$ and $K$, and the students identified more than three sides, without stating that some sides are actually the same and that they will overlap when the cube is folded. In our opinion, the students, while observing the net of the cube and performing a mental folding of the cube, did not pay attention to the tacit knowledge that Fischbein (1993) wrote about.

In this particular example, they overlooked the possibility that three edges can be drawn from one vertex. In the second task (see Figure 10), where they were asked to write down the faces perpendicular to the face $a$, the students often did not write down some of the faces. This error suggests that students, at the moment of folding the net of the cube and observing it, fail to remember that a cube has six faces and that every face has one face opposite and

Table 5. Achievement on the first task related to the concepts of a cube and the net of a cube and the repeated task related to the concepts of a cube and the net of a cube.

\begin{tabular}{ccc}
\hline $\begin{array}{c}\text { Number of } \\
\text { correct answers to } \\
\text { instructions }\end{array}$ & $\begin{array}{c}\text { The first task related to the concepts of a } \\
\text { cube and the net of a cube f }(\%)\end{array}$ & $\begin{array}{c}\text { Repeated first task related to the } \\
\text { concepts of a cube and the net of a cube } \\
\mathrm{f}(\%)\end{array}$ \\
\hline 3 & $11(32.4 \%)$ & $13(38.2 \%)$ \\
2 & $15(44.1 \%)$ & $9(26.5 \%)$ \\
1 & $3(8.8 \%)$ & $4(11.8 \%)$ \\
0 & $5(14.7 \%)$ & $8(23.5 \%)$ \\
\hline $\mathrm{N}=34$ & & \\
\hline
\end{tabular}


Table 6. Achievement on the second task related to the concepts of a cube and the net of a cube and the repeated task related to the concepts of a cube and the net of a cube.

\begin{tabular}{ccc}
$\begin{array}{c}\text { Number of } \\
\text { correct answers to } \\
\text { instructions }\end{array}$ & $\begin{array}{c}\text { The second task related to the concepts of } \\
\text { a cube and the net of a cube f }(\%)\end{array}$ & $\begin{array}{c}\text { The repeated second task related to the } \\
\text { concepts of a cube and the net of a cube } \\
\mathrm{f}(\%)\end{array}$ \\
\hline 2 & $14(50.0 \%)$ & $24(85.7 \%)$ \\
1 & $11(39.3 \%)$ & $3(10.7 \%)$ \\
0 & $3(10.7 \%)$ & $1(3.6 \%)$ \\
\hline
\end{tabular}

$\mathrm{N}=28$

parallel to it, while with other four faces it has a relationship of perpendicularity. Duval (1998) emphasizes that operative apprehension (when a figure be modified manipulative or mentally in several ways) is independent of the logical processes involved in solving manipulative tasks, but Fischbein (1993) recommends the tasks of folding and reconstructing a net of a cube where operations on the figures and definitions occur simultaneously.

\section{Conclusion}

Fischbein (1993) coined the term 'figural concept' to emphasize the fact that we are dealing with a specific type of mental objects. In the process of making mathematical discoveries, students usually experiment, use analogies and proof by induction, manipulating figural concepts, internal images controlled by concepts, instead of manipulating simple images or purely formal axiomatic constraints (Đokić, 2017; Đokić \& Zeljić, 2017; Đokić et al., 2019; Fishbein, 1993; Lemonidis, 1997). The processes of problem solving and discovery cannot be fully explained or described in geometry instruction without resorting to figural concepts. A figural concept and a definition concept interact in a cognitive activity (performed by a child or an adult), acting in unison in some situations, and contradicting one another in other situations. According to Fischbein (1993), the fact that figural concepts are not formed naturally, in line with their ideal forms, is one of the main reasons why geometry topics are such hard topics in the school curricula. Bearing this in mind, one of the main objectives of geometry education is creating different types of didactical situations that would systematically require a strong cooperation between the two aspects that reduce the gap between figure and concept.

The complex role of the concept image in geometric reasoning, on one hand, cannot be introduced without providing an example (a model and/ or drawing a figure), and on the other, individual examples of the concepts are never sufficient for working out a full definition of a concept. Consequently, specific elements of an example, even if they are not relevant for the mathematical definition of a concept, become the key elements which characterise the concept, e.g. a prototype example, according to Vinner and Hershkowitz (in Dreyfus, 2014: 50). Therefore, figures can have a 'deep' impact on the formation of concepts. For this reason, it is justifiable to say that a concept image is 'inherently personal'.

Our motivation to explore didactical situations was the situation described by Fischbein (1993) and Mihailo Petrović Alas (in Dejić, 2001) about theorems of Eudemus of Rhodes and Thales of Miletus. Their comments presented earlier in this paper made us conclude that image and wrong construction can lead to incorrect reasoning. For this reason, our paper was aimed at identifying and finding such situations in the work with pre-service primary school teachers, such as the examples of correct and incorrect reasoning in geometry tasks pro- 
vided. The general hypothesis that a figure plays an important role in the pre-service primary school teachers' reasoning was the starting point in our research, given that students (pre-service teachers) disregard the formal constraints of the concepts (angle and cube) in the tested situations, which our research confirmed. There is a correlation between the definition of an angle and identifying the points appertaining to the prototypical image of an angle, but many students who define an angle correctly, when observing the image, fail to identify the vertex of the angle as a part of the figure. The importance of the image in students' reasoning is also confirmed by the fact that they are more successful at identifying the points appertaining to the prototypical image of an angle than at identifying the points appertaining to an angle of a polygon (rectangle). Given that the cooperation between logical requirements and figural concepts can be hampered in the situations involving the net of a cube, these requirements are recommended as a perfect opportunity for developing the pre-service primary school teachers' reasoning (Fischbein, 1993), whereas an image can be useful only in specific and less complex situations.

The primary school teachers' knowledge impacts the design of instructions, as well as the selection of tasks and examples. Drawing upon the act of defining elaborated by Edwards and Ward (2008), we believe that it is important for the pre-service and in-service primary school teachers to know the key attributes of geometric objects, understand definitions and the role of definitions in mathematics, as well as to know how to select the proper examples that impact the planning of activities involving these objects (Guo \& Pang, 2011; Tsamir et al., 2015). Ac- cording to Al-Murani et al. (2019) and Guo \& Pang (2011), learning a mathematical concept by comparing examples is the importance of variation. Here, we see the potential of the Variation Theory (AlMurani et al., 2019; Guo, \& Pang, 2011), i.e., the use of variation to analyse the examples of a paradigm shift in teaching primary mathematics. Finally, in the light of Fischbein's theory (1993), we think that it is necessary to work on figural (pictoral) and conceptual aspects of geometric objects to resolve conflict situations and strengthen the understanding of the correlation between figural and conceptual properties in the initial geometry instruction.

From a broader perspective, cognitive psychology relies on the socio-cultural theory which places mathematical knowledge not only in a strictly scientific framework, but also in a socio-cultural framework (Bingolbali \& Monaghan, 2008; Walshaw, 2018). Revising the concept image, Bingolbali and Monaghan (2008) explore teaching practice and departmental perspectives on one hand, and cognitive aspects and individual mind on the other, and we agree with their conclusion that students' (pre-service teachers) departmental affiliations should not be ignored in the further research of the concept images.

\section{Acknowledgement}

The authors would like to express their deep gratitude to Professor Charalampos E. Lemonidis for his help in doing the historical aspects of this article and useful remarks on this part of the research work, and for his advice and assistance in psychological and epistemological points of view of the research problems. 


\section{References}

- Al-Murani, T., Kilhamn, C., Morgan, D. \& Watson, A. (2019). Opportunities for learning: the use of variation to analyse examples of a paradigm shift in teaching primary mathematics in England. Research in Mathematics Education, 21 (1), 6-24. DOI: 10.1080/14794802.2018.1511460.

- Andrić, V. (2018). Pedagogical Work of Mihailo Petrović Alas (1868-1943) - On the occasion of Mihailo Petrovićs 150th anniversary. The Teaching of Mathematics, 21 (1), 29-37. Retrieved November 13, 2019. from http://www.teaching.math.rs/vol/tm2113.pdf

- Bingolbali, E. \& Monaghan, J. (2008). Concept image revisited. Educational Studies in Mathematics, 68 (1), 19-35. DOI: 10.1007/s10649-007-9112-2

- Cohen, J. W. (1988). Statistical power analysis for the behavioral sciences (2 ${ }^{\text {nd }}$ ed.). Hillsdale, NJ: Lawrence Erlbaum Associates.

- Dejić, M. (2001). Prikaz manje poznatih radova Mihaila Petrovića Alasa, namenjenih nastavnicima i učenicima osnovnih i srednjih škola. Pedagoška stvarnost, 47 (7-8), 612-623.

- Dejić, M. (2013). Broj, mera, bezmerje. Beograd: Učiteljski fakultet.

- Dejić, M. (2020). Mihailo Petrović Alas's contribution to development of interest for mathematics. Teaching Innovations, 33 (1), 97-106, DOI: 10.5937/inovacije2001097D.

- Dreyfus, T. (2014). Solid Findings: Concept Images in Students' Mathematical Reasoning. Newsletter of the European Mathematical Society, 93, 50-52.

- Duval, R. (1998). Geometry from a cognitive point of view. In: Mammana, C. \& Villani, V. (Eds.). Perspectives on the teaching of geometry for the 21st century (37-52). Dordrecht: Kluwer.

- Đokić, O. (2017). Realno okruženje u početnoj nastavi geometrije. Beograd: Učiteljski fakultet.

- Đokić, O., Zeljić, M. (2017). Teorije razvoja geometrijskog mišljenja prema Van Hilu, Fišbajnu i UdemonKuzniaku. Teme, 41 (3), 623-637. DOI: 10.22190/TEME1703623D.

- Đokić, O., Jelić, M. \& Ilić, S. (2019). The Relationship between Images and Concepts in the Initial Geometry Teaching. In: Lawrence, S., Mihajlović, A. \& Đokić, O. Proceedings of the Training Conference History of Mathematics in Mathematics Education (29-40). October 26-30, 2018, Jagodina, Serbia. Jagodina: Fakultet pedagoških nauka.

- Edwards, B. S. \& Ward, M. B. (2004). Surprises from mathematics education research: student (mis)use of mathematical definitions. The American Mathematical Monthly, 111 (5), 411-424. DOI: 10.2307/4145268

- Edwards, B. S. \& Ward, M. B. (2008). The Role of Mathematical Definitions in Mathematics and in Undergraduate Mathematics Courses. In: Carlson, M. \& Rasmussen, C. (Eds.). Making the Connection: Research and Teaching in Undergraduate Mathematics Education (223-232). Mathematical Association of America. DOI: 10.5948/UPO9780883859759.018

- Fischbein, E. (1993). The Theory of Figural Concepts. Educational Studies in Mathematics. 24 (2), 139-162. DOI: $10.1007 / \mathrm{BF} 01273689$

- Fischbein, E. \& Nachlieli, T. (2006). Concepts and figures in geometrical reasoning. International Journal of Science Education, 20 (10), 1193-1211. DOI: 10.1080/0950069980201003

- Franke, T. M., Ho, T. \& Christie, C. A. (2012). The Chi-Square Test: Often Used and More Often Misinterpreted. American Journal of Evaluation, 33 (3) 448-458. DOI: 10.1177/1098214011426594 
- Furinghetti, F. (2019). History and epistemology in mathematics education. International Journal of Mathematical Education in Science and Technology, 1-28. DOI: 10.1080/0020739X.2019.1565454

- Gal, H. \& Linchevski, L. (2010). To see or not to see: analyzing difficulties in geometry from the perspective of visual perception. Educational Studies in Mathematics, 74 (2), 163-183. DOI: 10.1007/s10649-010-9232-y

- Gulikers, I. \& Blom, K. (2001). A Historical Angle - A Survey of Recent Literature on the Use and Value of History in Geometrical Education. Educational Studies in Mathematics, 47 (2), 223-258. DOI: 10.1023/A:1014539212782

- Guo, J. \& Pang, M. (2011). Learning a mathematical concept from comparing examples: The impotance of variation and prior knowledge. European Journal of Education, 26 (4), 495-525. DOI: 10.1007/s10212-011-0060-y

- Hershkowitz, R. (1987). The Aquisition of Concepts and Misconception in Basic Geometry - Or When "A Little Learning is a Dangerous Thing". In: Novak, J. (Ed.). Proceedings of the second international seminar Misconceptions and Educational Strategies in Science and Mathematics 3 (238-252). 26-29 July 1987. Ithaca, NY: Cornell University.

- Kidron, I. (2011). Constructing knowledge about the notion of limit in the definition of the horizontal asymptote. International Journal of Science and Mathematics Education, 9 (6), 1261-1279. DOI: 10.1007/s10763-0109258-8

- Lawrence, S. (2014). Mathematics Education in the Balkan Societies Up To the WWI. Teaching Innovations, 27 (3), 46-57. DOI: 10.5937/inovacije1403046L

- Lemonidis, C. (1997). A few remarks regarding the teaching of Geometry, through a theoretical analysis of the geometrical figure. Nonlinear Analysis, 30 (4), 2087-2095. DOI: 10.1016/S0362-546X(97)00294-0

- Shimizu, S. et al. (2012). Fun with MATH for elementary school (Grade 4, part B). Osaka, Japan: KEIRINKAN.

- Sinclair, N. \& Bruce, C. (2015). New opportunities in geometry education at the primary school. ZDM Mathematics Education, 47 (3), 319-329. DOI 10.1007/s11858-015-0693-4

- Tsamir, P., Tirosh, D., Levenson, E., Barkai, R. \& Tabach, M. (2015). Early-years teachers' concept images and concept definitions: triangles, circles, and cylinders. ZDM Mathematics Education, 47 (3), 497-509. DOI: 1 0.1007/s11858-014-0641-8

- Vinner, S. (2018). Mathematics, Education, and Other Endangered Species: From Intuition to Inhibition. Springer International Publishing. DOI: 10.1007/978-3-319-90035-3

- Walshaw, M. (2018). Epistemological Questions About School Mathematics. In: Ernest, P. (ed.). The Philosophy of Mathematics Education Today. ICME-13 Monographs (161-171). Springer International Publishing. DOI: 10.1007/978-3-319-77760-3_10 
The Correlation between Figural and Conceptual Properties of Angle and Cube in Pre-Service Teachers Geometric Reasoning

\author{
Оливера Ј. Ђокић, Мила С. Јелић, Светлана М. Илић
}

Универзитет у Београду, Учитељски факултет

\title{
ПОВЕЗАНОСТ СЛИКОВНИХ И ПОЈМОВНИХ СВОЈСТАВА УГЛА И КОЦКЕ У ГЕОМЕТРИЈСКОМ РЕЗОНОВАҢУ БУДУЋИХ УЧИТЕЉА
}

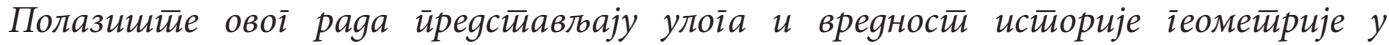

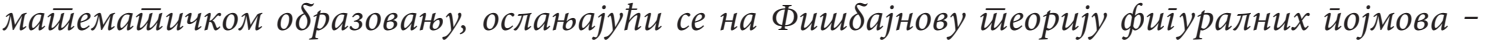
ирва исӣоријска йачка са којом иравимо коичу су йеореме Еуgема са Pоgоса и Талеса из

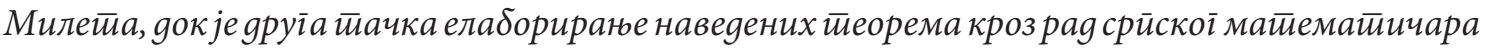

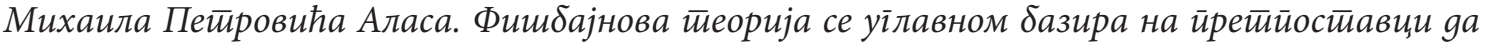

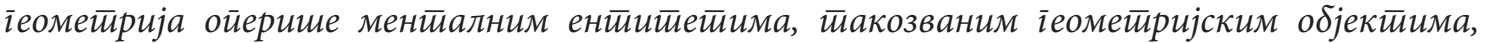

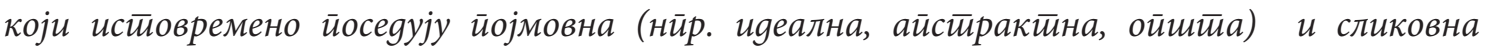

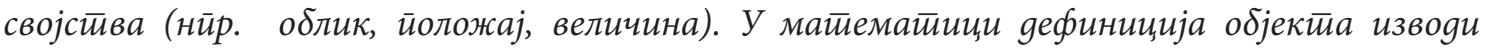

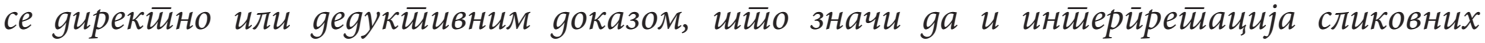

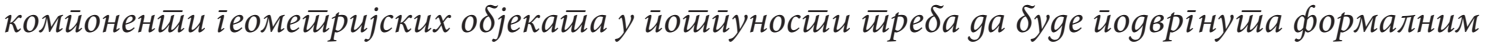
оіраниченима која йроистиччу из gефиниција. Међуйим, Винер и Херсхковии, (вияи у Drеуfus, 2014: 50) истиччу gа іеометиријско резоноване ученика не мора нужно gа буgе засновано

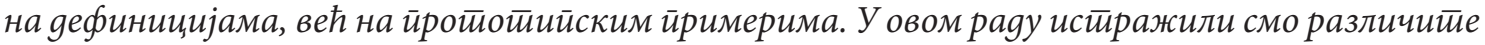

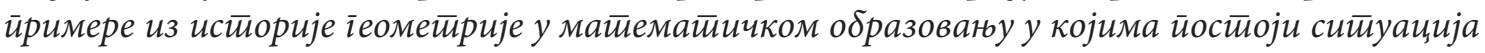

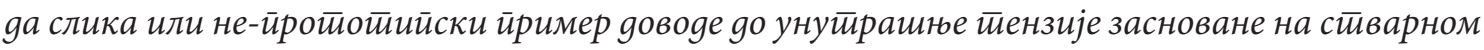

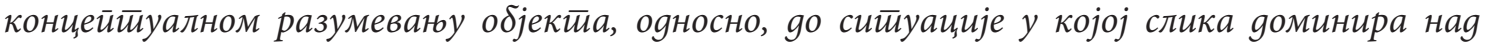
бормалном дефиницијом. Појмовна слика (Vinner, Hershkowitz, Tall, виgu у Dreyfus, 2014: 5), gефинисана као свеукуйна коінитиивна сиирукйура која је у уму йојеgиниа йовезана са йојмом (нйр. слике, йримери, речи), може gа оясииуйа оg формалне gефиниције йојма (Drеу-

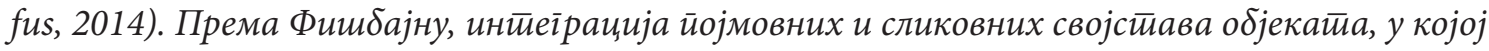
йојмовна оіраничень gоминирају наg сликовним, није ӣриродан йроцес. Винер, Херсхковии, и

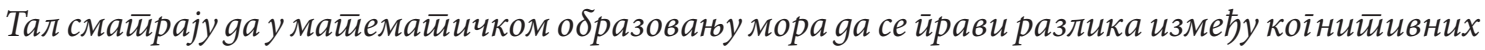

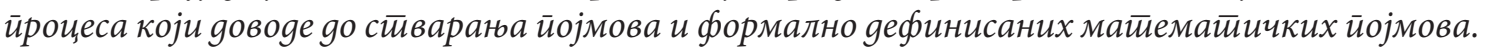
Овај ирроцес захиева конииинуирано, системаиично и иеемељно иррииремане насииавника.

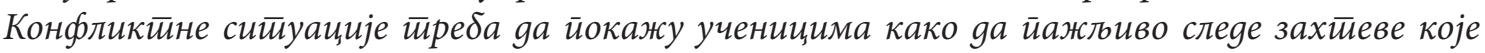

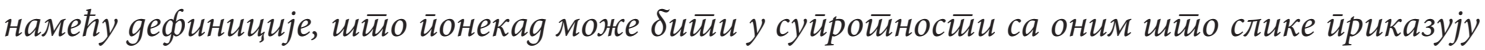
(или намећу).

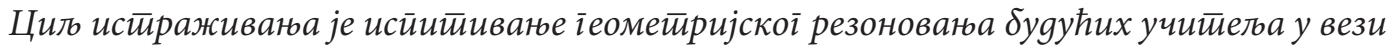
са йовезаношћу сликовних (фиіуралних) и йојмовних својстиава іеометиријских објекайа.

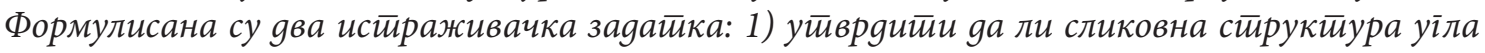

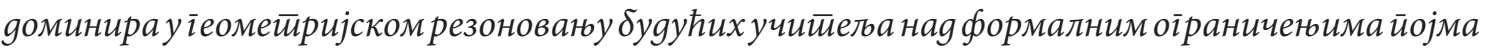

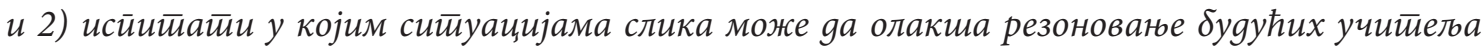

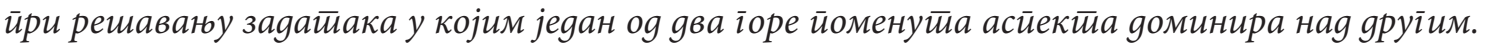

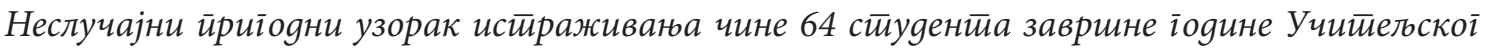

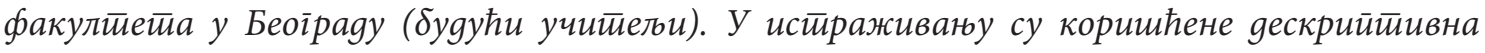




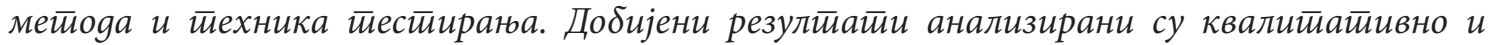

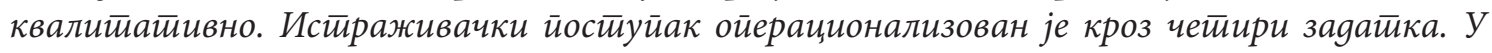

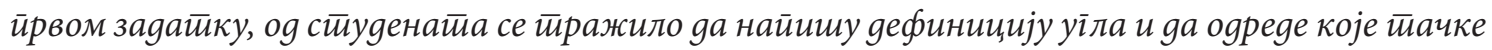

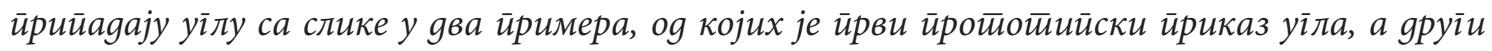

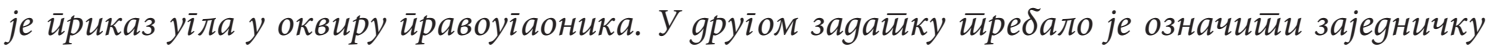

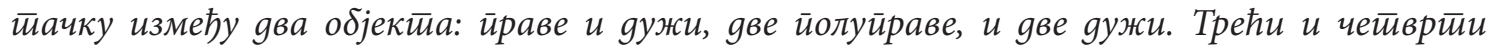

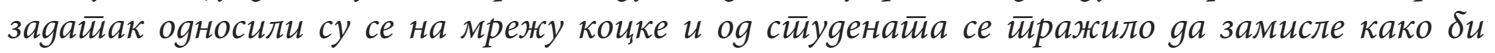

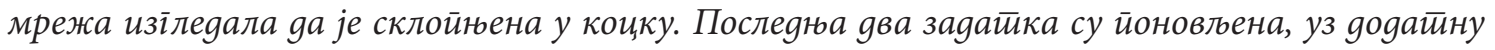

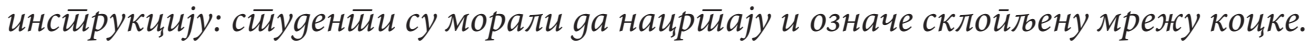

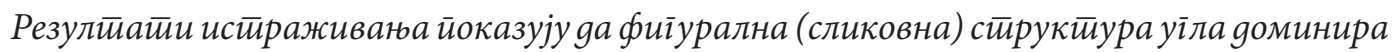
у іеомейријском резоновану буgућих учииельа наg формалним оіраниченима ӣојма. Чак и

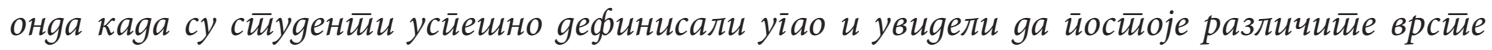

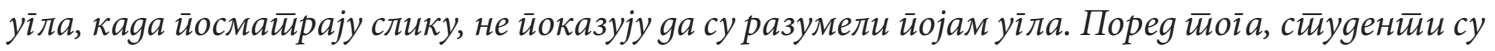

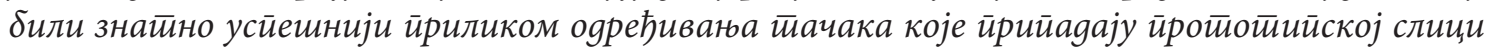

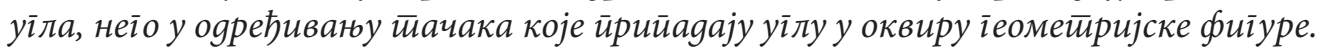

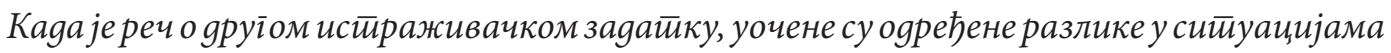

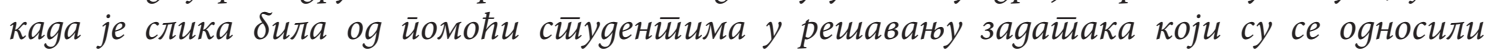

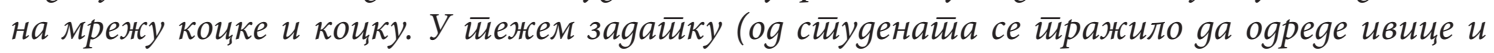

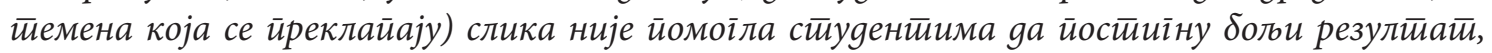

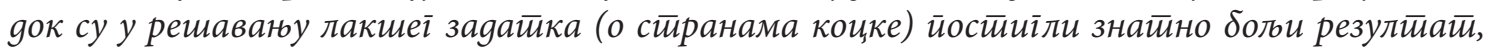

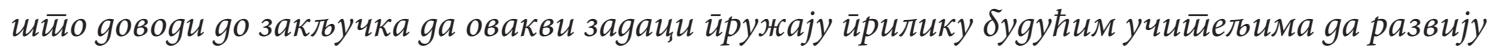

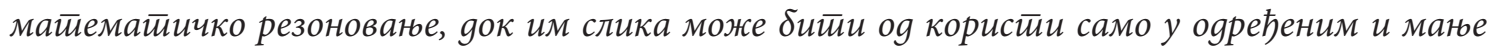
сложеним сийуацијама.

Наш зактучак је gа је неойходно раяит̄и на фиіурралним (сликовним) и йојмовним

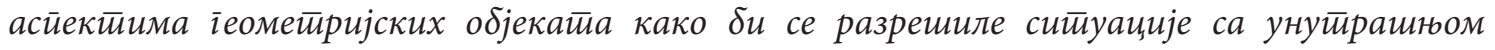
иензијом и ојачало разумеване корелације између фиіуралних и йојмовних својсйава

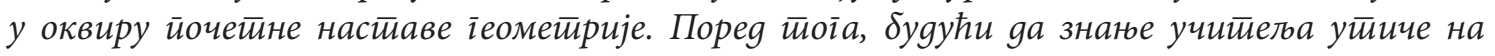

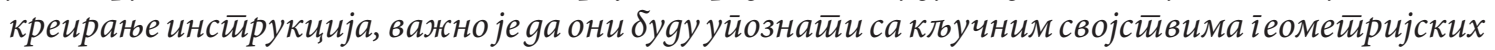

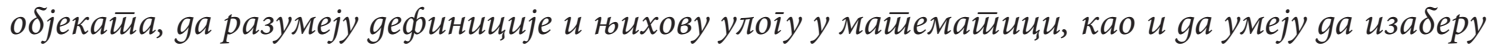

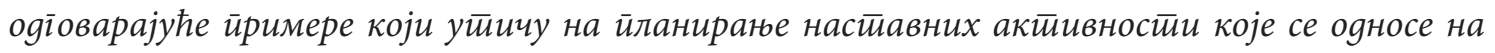
іеометиријске објекйе.

Клучне речи: истиорија іеометирије, фиіурални иојам, іеомейријска дефинииија, инстирукиија, іеометиријско резоноване. 